\title{
The cases of June 2000, November 2002 and September 2002 as examples of Mediterranean floods
}

\author{
M. Milelli ${ }^{1}$, M. C. Llasat ${ }^{2}$, and V. Ducrocq ${ }^{3}$ \\ ${ }^{1}$ Arpa Piemonte, Torino, Italy \\ ${ }^{2}$ University of Barcelona, Barcelona, Spain \\ ${ }^{3}$ Météo-France - CNRM/GMME, Toulouse, France \\ Received: 24 October 2005 - Revised: 30 January 2006 - Accepted: 20 February 2006 - Published: 2 May 2006 \\ Part of Special Issue "HYDROPTIMET"
}

\begin{abstract}
Four flood events that affected three different countries are here described in terms of meteorological genesis and in terms of consequences on the population and on the territory. Each event is a good representative of a class of phenomena that produce important effects on the urban and extra-urban tissue and that must be taken into account in an optic of civil protection and risk evaluation. This is the subject of the HYDROPTIMET project, part of the Interreg IIIB program, which is collocated in the framework of the prevention of natural hazards and, in particular, those related to severe meteo-hydrological events. This paper aims at being a general introduction of the four events which are the subject of more detailed studies, already published or under submission.
\end{abstract}

\section{Introduction}

Floods are the most common kind of natural hazard in the Western Mediterranean region, where, during recent years, all the countries had to face with some intense floods and their consequences. Two main categories of floods may be distinguished in this area, according to the catchments characteristics. On the one hand, when a flood happens within a large river basin, affecting large portions of the plain, huge economic damages are expected to buildings and infrastructures, but frequently there is enough time to limit the loss of human lives. Examples of works on this subjects are Arreola et al. (2002), Boni et al. (1996), Llasat et al. (1999), M.I.S. de l'Eau (1993) and Ramis et al. (1994). On the other hand, when a flood is triggered by an intense rainfall over small catchments (flash floods), the main cost is in terms of human lives, because its rapidity does not permit the actuation of alert procedures (see for instance Chastan et al., 1993;

Correspondence to: M. Milelli

(m.milelli@arpa.piemonte.it)
Comby, 1993; Doswell et al., 1996; Sénési et al., 1996, and Riosalido et al., 1997). In any case, any procedure modifying the exposure of lives and properties to floods, such as flood forecasting and warning, do not avoid the occurrence and the effects of floods, but is aimed at limiting their social and economic cost.

In this context, the EU project HYDROPTIMET funded within the Interreg IIIB Medocc program, has been developed (http://hydroptimet.medocc.org). Its goal is the improvement of the knowledge of these severe events phenomena, the optimisation of the meteorological and hydrological aspects for the prevention of natural hazards, the experimentation of new tools (such as numerical models) to be used operationally for the Quantitative Precipitation Forecast (QPF), for the Quantitative Discharge Forecast (QDF) and the improvement of the collaboration between the partners (exchange of data, methodologies, information). For this purpose, four events have been chosen to be analysed. They fall into the categorization that we propose before and, in particular, they are listed in Table 1.

The regions affected by the events are shown in Fig. 1 . They all belong to the North-Western part of the Mediterranean basin and a complex orography characterizes them: high mountains, narrow valleys, plains and the coastline are sometimes very close. The particular topography (with the presence of Alps, Apennines, Pyrenees and Massif Central), can heavily interact with the atmospheric flow, in particular with the approaching upper-level troughs, which could trigger range of mesoscale phenomena such as lows moving into the Western Mediterranean Sea and affecting the countries which are along their trajectory. Moreover quasi-stationary mesoscale convective systems may develop in the warm sector of a frontal disturbance, and may be kept in place by the orography inducing large amounts of precipitation in less than $24 \mathrm{~h}$.

Consequently, the aim of this paper is to show an example of each kind of Western Mediterranean floods evidencing

Published by Copernicus GmbH on behalf of the European Geosciences Union. 
Table 1. The HYDROPTIMET test cases.

\begin{tabular}{ccc}
\hline Name & Date & Characteristics \\
\hline $\begin{array}{c}\text { Piedmont 1 } \\
\text { (Italy) }\end{array}$ & 14-16 Nov 2002 & extended flood \\
$\begin{array}{c}\text { Piedmont 2 } \\
\text { (Italy) }\end{array}$ & 23-26 Nov 2002 & extended flood \\
Gard & 8-9 Sep 2002 & flash flood \\
$\begin{array}{c}\text { (France) } \\
\text { Montserrat } \\
\text { (Spain) }\end{array}$ & 9-10 June 2000 & flash flood \\
\hline
\end{tabular}

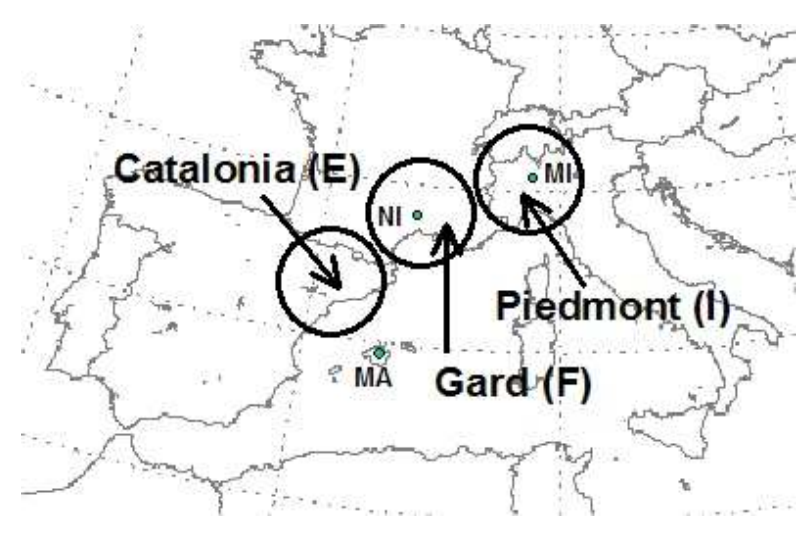

Fig. 1. Domain of the Western Mediterranean region with the three areas hit by the events described in the work. The green dots represent the radiosounding stations used: Milan (MI), Nîmes (NI), Palma de Mallorca (MA).

their main synoptic features, trying to find common ingredients and so posing the background for different and more detailed analysis performed by other authors from other points of view. In particular we would like to stress the relationship between large-scale meridional flow, mesoscale structures and local orographic effects in the onset of strong rain events, taking inspiration from other works, such as Plaut et al. (2001) who classified the large-scale flow patterns leading to heavy precipitations over the Alpine chain or Rotunno and Ferretti (2001) who gave particular emphasis on topographic enhancement of precipitation. Table 2 shows a list of works related to the discussed events.

The paper is organized as follows: in Sect. 2 we describe the two Piedmont cases; then we present the Gard and the Montserrat events in Sects. 3 and 4, respectively; eventually the main conclusions are drawn in Sect. 5 with a comparison among the main features of the four events.
Table 2. Works based on the described events.

\begin{tabular}{cc}
\hline Piedmont Cases & Elementi et al. (2005), \\
& Rabuffetti and Milelli (2005), \\
& Taramasso et al. (2005) \\
Gard Case & Delrieu et al. (2005), \\
& Ducrocq et al. (2003), \\
& Huet et al. (2003) \\
Montserrat Case & Mariani et al. (2005), \\
& Zampieri et al. (2005), \\
& Llasat et al. (2003), \\
Overall Comparison & Rigo and Llasat (2005) \\
& Lacava et al. (2005), \\
& Romero et al. (2005), \\
& Anquetin et al. (2005) \\
Inherent thematics & Delitala (2005) \\
\hline
\end{tabular}

\section{Analysis of the Piedmont events}

The description of the events, with the meteorological genesis and the consequences from an hydrological point of view, are taken from an internal report (A.R.P.A. Piemonte, 2002) by Arpa Piemonte, which is available on line at the address http://www.arpa.piemonte.it (in Italian).

\subsection{Synoptic conditions: first case (14-16 November 2002)}

This event occurred between 14 and 16 November 2002 in Piedmont (Fig. 2), and was originated by the development and the expansion of an upper-level low, which gradually moved from the Atlantic Ocean towards Italy. For a better comprehension of the phenomenology of the event, it is appropriate to analyse the pre-existent synoptic conditions, starting from 12 November. That morning was characterized by the presence of a weak ridge over the Central Mediterranean Sea and a trough stretching from North-Western Europe to the Atlantic coastline of the Iberian Peninsula.

During that day, the axis of the trough gradually moved Eastward, causing therefore the upper levels winds to become South-Westerly over all Northern Italy. At the same time the sea level pressure decreased over Piedmont. This situation remained almost unchanged during 13 November except for the onset of precipitation over the Western Alps. In the following days, 14 and 15 November, the synoptic situation was characterized by a further extension of the Atlantic trough towards Northern Africa (Fig. 3), with a latitudinal extension of the polar jet stream, reaching Morocco. This provided a strong southerly flow over the Western Alps.

The sea level pressure was characterized by the motion of a minimum from Ireland to the Iberian Peninsula (Fig. 4), and by the formation of a secondary minimum starting from the afternoon of 15 November: this minimum formed over the 


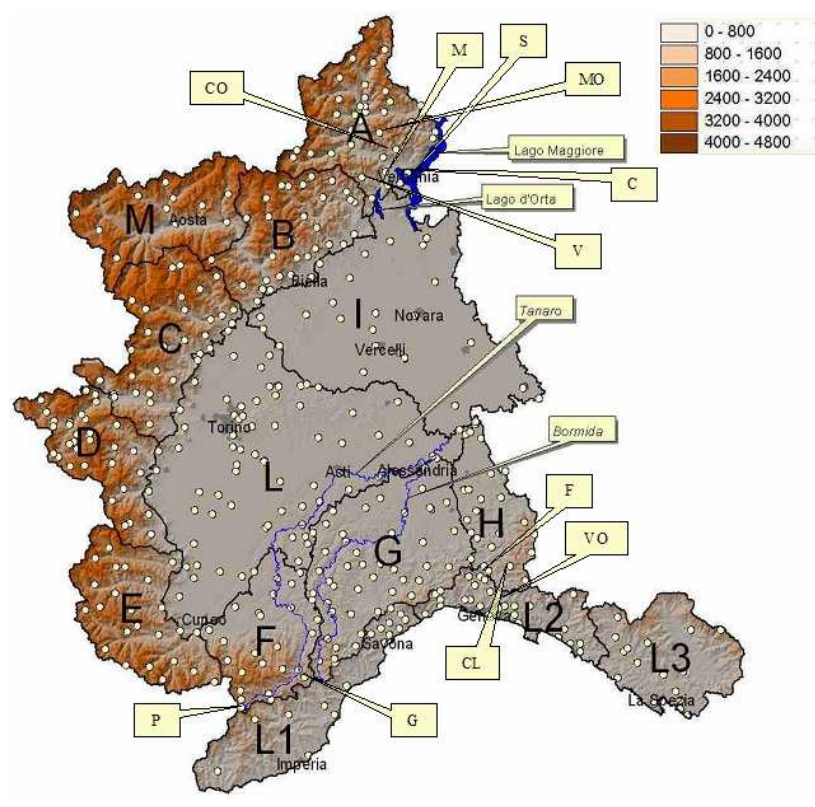

Fig. 2. Location of the rain gauges of the Piedmont, Val d'Aosta and Liguria high resolution networks with the respective warning areas (basins) which are characterized on the base of hydrologic and geologic criteria (homogenous hydrogeological answer to intense meteorological events) and with meteorological, climatological and orographic criteria. The names of the rivers, lakes and stations affected by the events are also indicated (see Table 3 for details). See Fig. 1 for the localization of the area.

Table 3. Names and labels of the lakes, rivers and localities affected by the events and named in this work.

\begin{tabular}{cc}
\hline M & Mergozzo \\
CO & Cursolo Orasso \\
C & Cossogno \\
V & Valstrona \\
MO & Montecrestese \\
S & Stresa \\
P & Piaggia \\
G & Garessio \\
CL & Carrega Ligure \\
VO & Vobbia \\
F & Fraconalto \\
\hline
\end{tabular}

Balearic Islands and gradually moved towards the Ligurian Gulf.

This synoptic configuration determined a strengthening of the moist flow over Piedmont and the intensification of the precipitation: from the morning of 14 November, it gradually extended to the whole region and the greatest values were recorded over the Southern mountains, where there was orographic updraft due to the interaction of the winds with
Table 4. Names and labels of the warning areas used in the work. The labels are indicated in Fig. 2.

\begin{tabular}{cc}
\hline A & Toce \\
B & Sesia \\
C & Orco \\
D & Dora Riparia \\
E & Varaita \\
F & Alto Tanaro \\
G & Belbo - Orta \\
H & Scrivia \\
I & Pianura Settentrionale \\
L & Pianur Meridionale \\
M & Valle d'Aosta \\
L1 & Ligure di Ponente \\
L2 & Genova \\
L3 & Magra \\
\hline
\end{tabular}

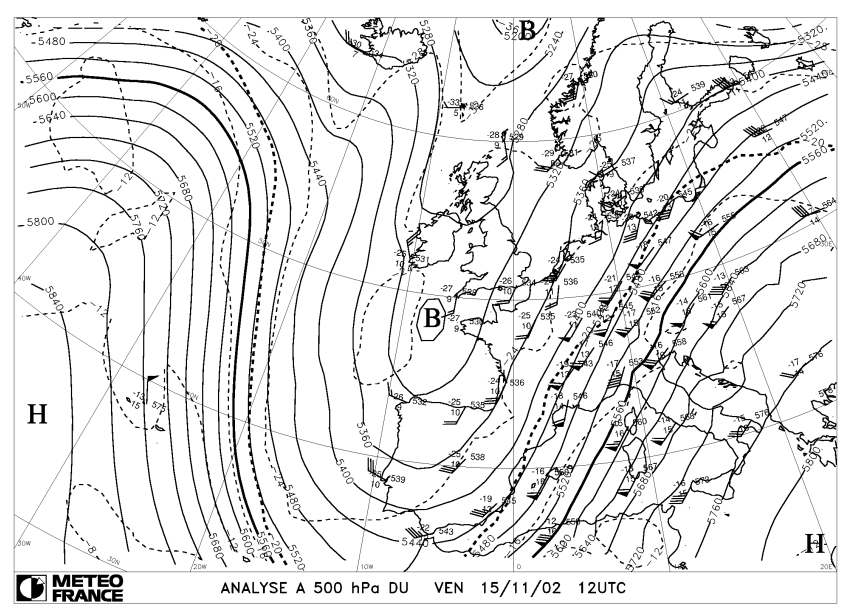

Fig. 3. 15 November 2002 12:00 UTC, analysis at $500 \mathrm{hPa}$ : geopotential (in $\mathrm{m}$ ) and temperature (in ${ }^{\circ} \mathrm{C}$ ) are drawn, respectively, as solid and dashed lines ( $\mathrm{H}$ for high centre and $\mathrm{B}$ for low centre of geopotential).

the Alps and the Apennines. Then the situation remained almost unchanged till the evening of 16 November (Fig. 5), when the sea level pressure minimum shifted towards NorthEastern Europe (Fig. 6) moving along the French and Swiss sides of the Alps. During the event, the temperature aloft did not change substantially; only in the night between 16 and 17 November, the passage of a cold front (Fig. 6) from West caused a fall of about $3^{\circ} \mathrm{C}$ in the temperature at $700 \mathrm{hPa}$ over the whole Region (A.R.P.A. Piemonte, 2002). 


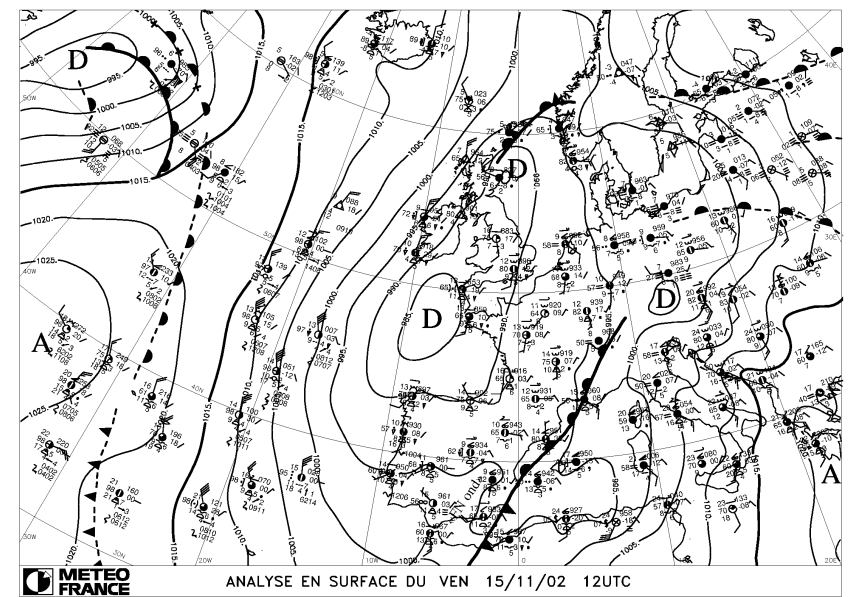

Fig. 4. 15 November 2002 12:00 UTC, surface analysis: slp (in $\mathrm{hPa}$ ) is shown by solid lines (A for high centre and $\mathrm{D}$ for low centre of slp).

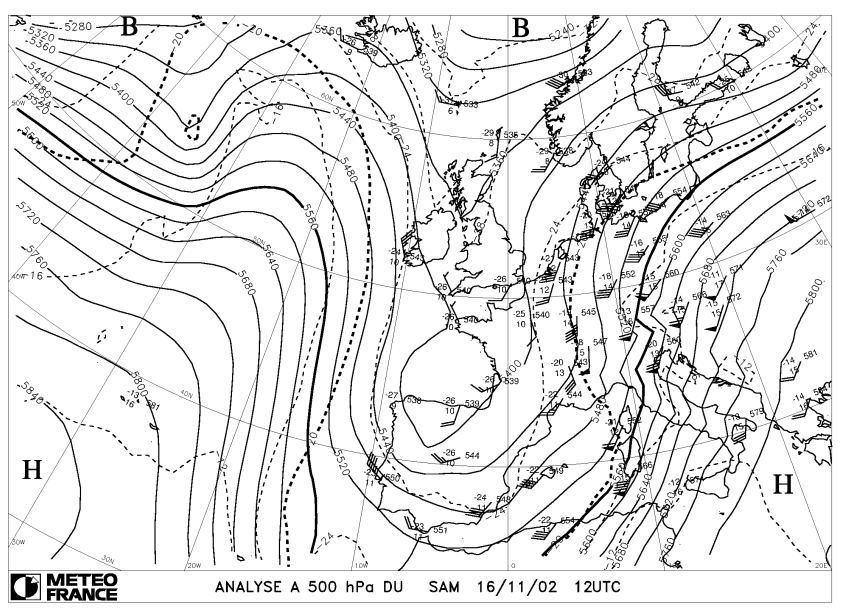

Fig. 5. 16 November 2002 12:00 UTC, analysis at $500 \mathrm{hPa}$ : geopotential (in $\mathrm{m}$ ) and temperature (in ${ }^{\circ} \mathrm{C}$ ) are drawn, respectively, as solid and dashed lines ( $\mathrm{H}$ for high centre and $\mathrm{B}$ for low centre of geopotential).

\subsection{Analysis of the impacts: first case}

In the days 14-16 November, the precipitation affected particularly the Toce area in the North and Alto-Tanaro in the South of Piedmont (Fig. 7). It has to be pointed out that the extension of the heavy precipitation areas over the French border plotted in Fig. 7, are the effect of the Cressman interpolation method (Cressman, 1959) adopted in this case; no data are actually available over the French territory. The maxima of precipitation accumulated in $72 \mathrm{~h}$ have been recorded in the Toce lowland with $490 \mathrm{~mm}$ in Mergozzo, $554 \mathrm{~mm}$ in Cursolo Orasso, $540 \mathrm{~mm}$ in Cossogno, and $560 \mathrm{~mm}$ in Valstrona (see Fig. 2 for their location and Table 3 and Table 4 for the labels and names correspondence).

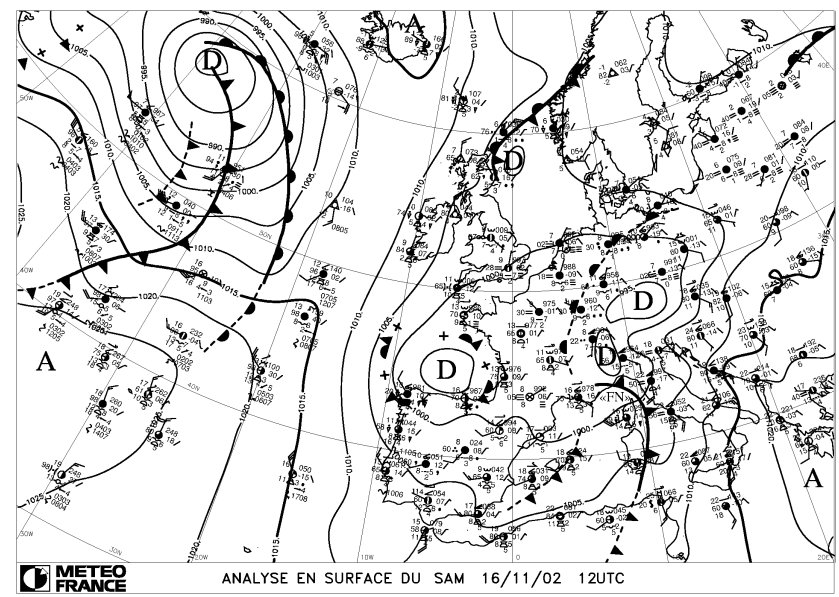

Fig. 6. 16 November 2002 12:00 UTC, surface analysis: slp (in $\mathrm{hPa}$ ) is shown by solid lines (A for high centre and D for low centre of slp).

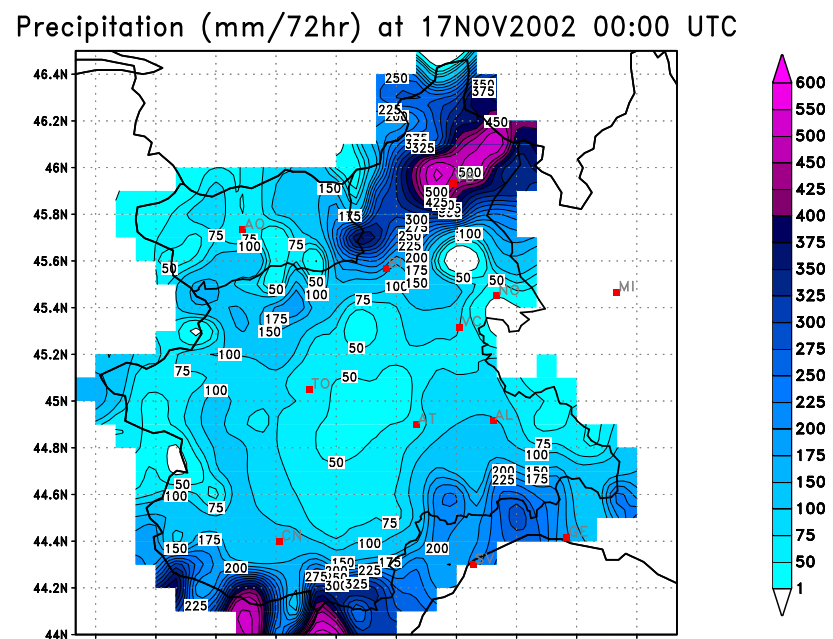

Fig. 7. Total observed precipitation in Piedmont from 14 to 16 November 2002. See Fig. 1 for the localization of the area.

In various rain gauges of the area (around $1500 \mathrm{~km}^{2}$ ) the total values recorded exceeded $400 \mathrm{~mm}$. In the Southern part (Alto Tanaro), the highest values of rain in $72 \mathrm{~h}$ were observed in Piaggia with $480 \mathrm{~mm}$ and in Garessio with $390 \mathrm{~mm}$, but important precipitations have been recorded also in the river basin of Scrivia with peaks of $250 \mathrm{~mm}$ in Carrega Ligure. The areal values were around $325 \mathrm{~mm}$ over the Toce basin, and $210 \mathrm{~mm}$ over Alto Tanaro in $72 \mathrm{~h}$. Such critical values have been compared with the return time curves, which indicate that the 20 years time was exceeded (A.R.P.A. Piemonte, 2002). In the Southern zones the peaks of precipitation have been recorded during 14 and 15 November while in the North-Western part the highest values of precipitation have been observed during 16 November. Only the Toce area 


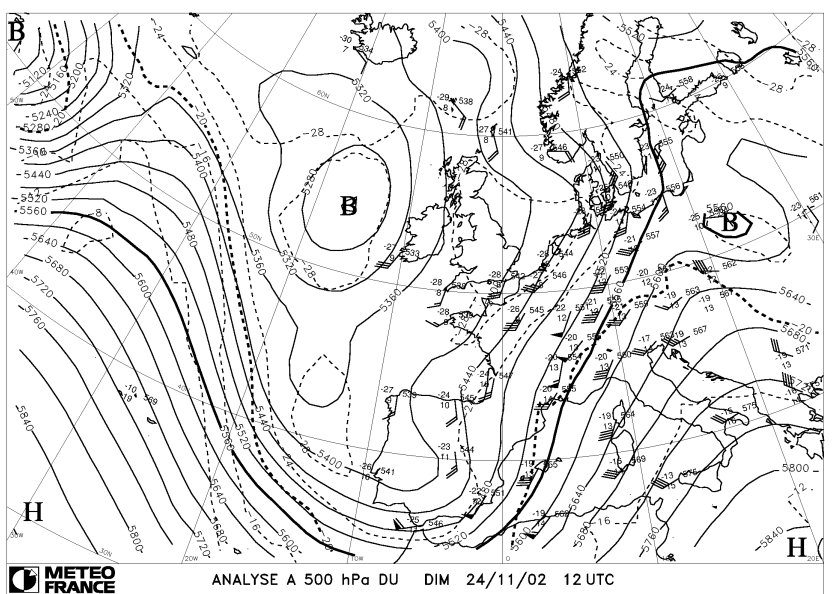

Fig. 8. 24 November 2002 12:00 UTC, analysis at $500 \mathrm{hPa}$ : geopotential (in $\mathrm{m}$ ) and temperature (in ${ }^{\circ} \mathrm{C}$ ) are drawn, respectively, as solid and dashed lines ( $\mathrm{H}$ for high centre and $\mathrm{B}$ for low centre of geopotential).

in the North of the region has been affected for the whole event (14-16 November).

The response of the hydrological network was particularly complex. In the Northern part of the region, the first increase in the rivers flux has been registered during 14 November, with few approaches to the warning levels, without overcoming. From the evening of 15 to the morning of 16 November though, the intensification of the precipitation brought to the overcoming of the warning levels in all the main rivers and, in particular, in the Maggiore Lake which overcame the warning threshold of $5 \mathrm{~m}$, reaching the level of $6.62 \mathrm{~m}$. In the Southern part of the region, the situation was similar: in fact, the main rivers (Tanaro and Bormida, 8000 and $2600 \mathrm{~km}^{2}$ catchments size respectively) had a first critical phase during 14 November, but the most important effects have been recorded the days after with overcoming of the attention thresholds.

All these areas were affected by some phenomena of hydrogeological instability with movements of land and localized floods. In particular, in the Northern provinces there were damages in the municipalities by the increase of the level of the Maggiore lake and in smaller degree by the one of the Orta lake. Also some retaining walls were destroyed. No casualties were registered during the entire event.

\subsection{Synoptic conditions: second case (24-26 November 2002)}

During the beginning of the third ten days of November, the synoptic situation was characterized by an upper-level trough with an associated surface cyclone standing off the Irish coastline, and by a ridge with the axis centred between Southern Italy and Greece. From 23 November, the trough began to expand Southward reaching the North-

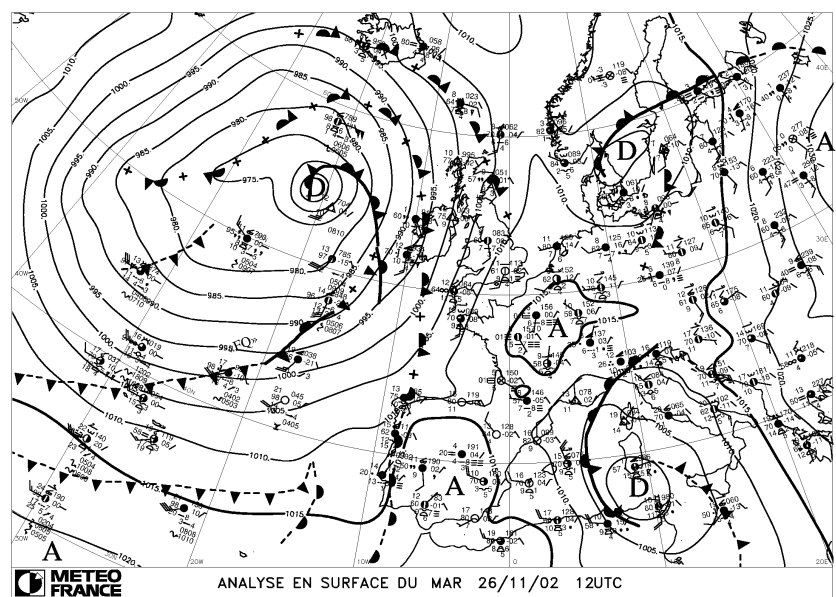

Fig. 9. 26 November 2002 12:00 UTC, surface analysis: slp (in $\mathrm{hPa}$ ) is shown by solid lines (A for high centre and D for low centre of slp).

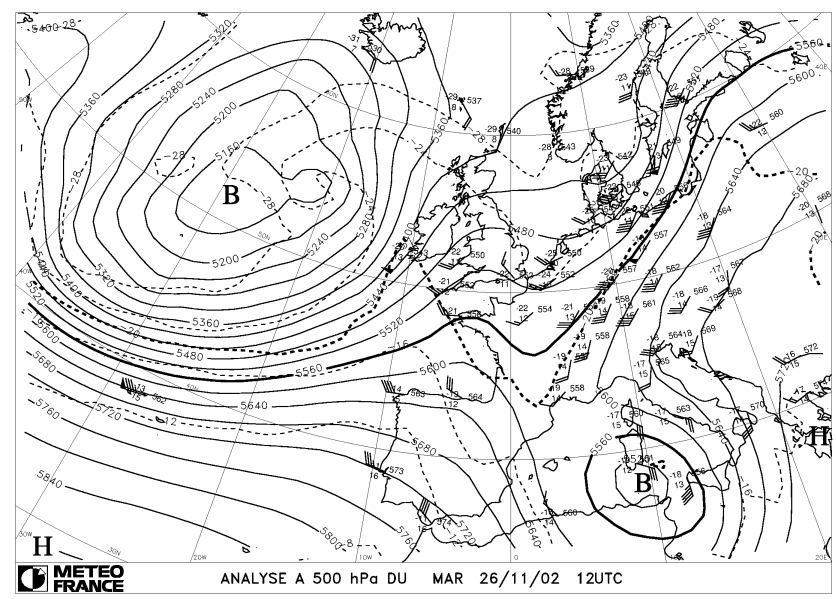

Fig. 10. 26 November 2002 12:00 UTC, analysis at $500 \mathrm{hPa}$ : geopotential (in $\mathrm{m}$ ) and temperature (in ${ }^{\circ} \mathrm{C}$ ) are drawn, respectively, as solid and dashed lines ( $\mathrm{H}$ for high centre and $\mathrm{B}$ for low centre of geopotential).

African coastline and directing a moist South-Westerly flow over Northern Italy (A.R.P.A. Piemonte, 2002).

During 24 November, the widening of the trough towards East caused a backing of the flow over Northern Italy from South (Fig. 8), with a general increase of humidity at all levels. This situation lasted also for the whole day after, when there was a further deepening of the trough over Northern Africa and a rotation of its axis towards East. During 26 November a deep low associated to a sea level pressure minimum, isolated over the Sardinia Channel and stayed stationary for about $24 \mathrm{~h}$, causing a very wet South-Easterly flow from the Tyrrhenian Sea towards Piedmont (see Fig. 9 and Fig. 10). 


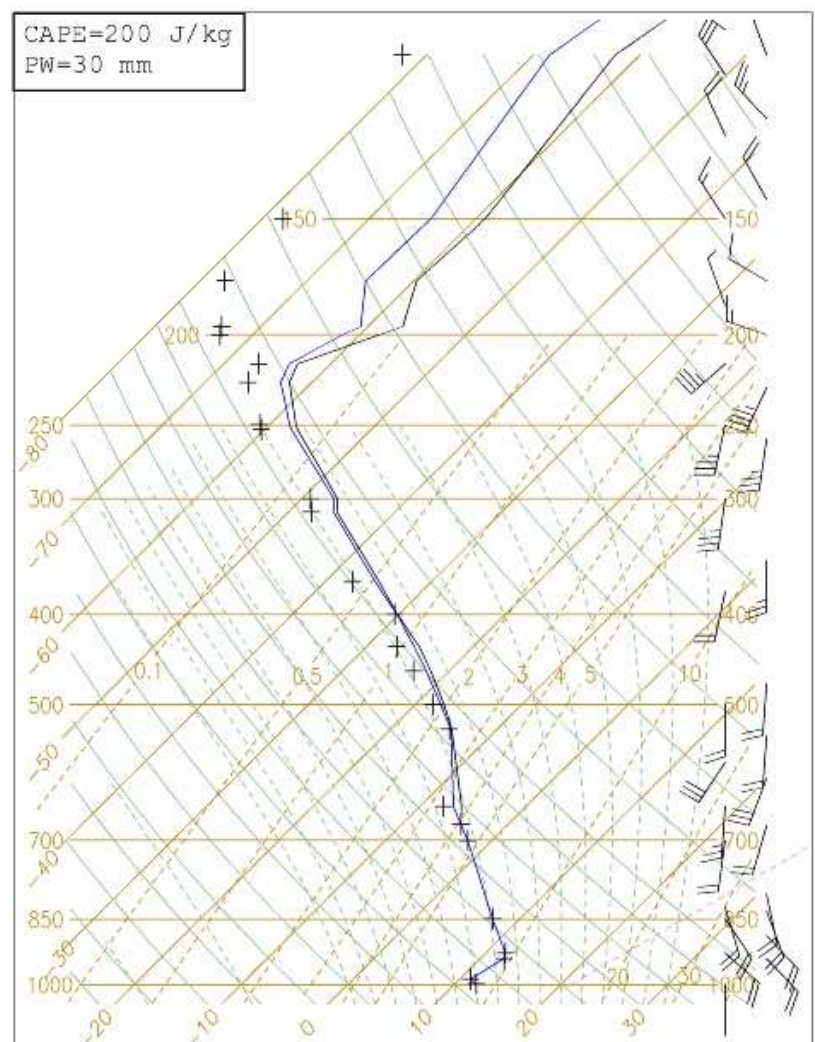

Fig. 11. 26 November 2002 17:00 UTC, Milan radiosounding: in the upper-left corner of the panel, CAPE stands for Convective Available Potential Energy $\left(\mathrm{Jkg}^{-1}\right)$ and PW for Precipitable Water (mm). The CAPE computation is based on the most unstable parcel. See Fig. 1 for the location of the station. On the right, the wind direction and intensity is displayed.

Finally, during 27 November, the Eastward movement of the low towards Southern Italy, favoured the weakening of the precipitation over Piedmont with an increase of the sea level pressure which passed from $1010 \mathrm{hPa}$ the 26 at 12:00 UTC to $1014 \mathrm{hPa}$ the 27 November at 00:00 UTC and then to $1019 \mathrm{hPa}$ during the following night.

The precipitation related to this event was heavy and continuous because of the long persistence of the wet Southerly winds: this flow caused typically orographic rain over the Northern part of the region, from the night of 23 to the morning of 27, and over the Apennines from the night of 23 to the evening of 26 November. The heaviest precipitation was recorded during the $24 \mathrm{~h}$ between 06:00 UTC of 26 and 06:00 UTC of 27 November with moderate values all over the region and very heavy rain on the Toce and Scrivia basins (see Sect. 2.4). In particular, on the Scrivia basin, the highest values were recorded during the first $6 \mathrm{~h}$ of 26 November.

Owing to the long duration of the Southerly flow, the height of the freezing level was constantly increasing from 23 November, when the mean value over North-Western Italy was around $1900 \mathrm{~m}$, to 26 November, with a mean value
Precipitation $(\mathrm{mm} / 72 \mathrm{hr})$ at $27 \mathrm{NOV} 2002$ 00:00 UTC

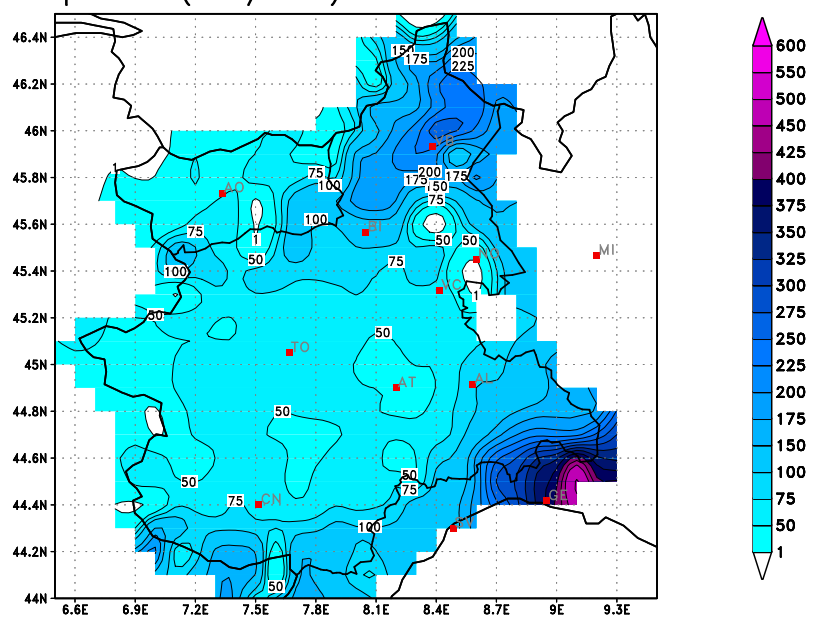

Fig. 12. Total observed precipitation in Piedmont from 24 to 26 November 2002. See Fig. 1 for the localization of the area.

around $2600 \mathrm{~m}$ (Fig. 11) and a further increase up to $2900 \mathrm{~m}$ the day after. This effect contributed to increase the amount of water discharged into the rivers during the event.

\subsection{Analysis of the impacts: second case}

The precipitation (Fig. 12) extended in particular over the Southern part of the region from 24 to 26 November (Scrivia area) with maxima of $442 \mathrm{~mm}$ in Vobbia, $360 \mathrm{~mm}$ in Carrega Ligure and $340 \mathrm{~mm}$ in Fraconalto, recorded in $72 \mathrm{~h}$; in smaller measure also the Northern part (Toce area) was affected with $260 \mathrm{~mm}$ in Montecrestese, $283 \mathrm{~mm}$ in Mergozzo and $235 \mathrm{~mm}$ in Stresa in $72 \mathrm{~h}$ (see Fig. 2 for their location and Table 3 and Table 4 for the labels and names correspondence). Considering the average rain over warning areas, the highest values have been recorded in the Scrivia basin $(\approx 250 \mathrm{~mm}$ in $72 \mathrm{~h})$ and in the Toce area $(\approx 150 \mathrm{~mm}$ in $72 \mathrm{~h})$. Such values have been compared with the return time curves, which indicate that the 20 years time was exceeded in the Scrivia area but not in the Toce one. Considering the kind of precipitation, it was persistent and diffuse with the exception of Vobbia (in correspondence with the Apennines watershed) where the rain gauge registered $76 \mathrm{~mm}$ in $3 \mathrm{~h}$ and $143 \mathrm{~mm}$ in $6 \mathrm{~h}$, indicating the presence of a localized system of convective cells which have been originated over the Western Mediterranean Sea and was moving Northwards, following the synoptic flux and affecting mainly the Ligurian side of the Apennines.

In the first phase of the event, from 24 to 25 November, the rain gave rise to ordinary floods of some small water courses in the South and in the North, and to a limited increase of the Maggiore Lake. During the second phase of the event, from the second part of 25 to the morning of 26, the intensification of the phenomena produced localized floods along the 


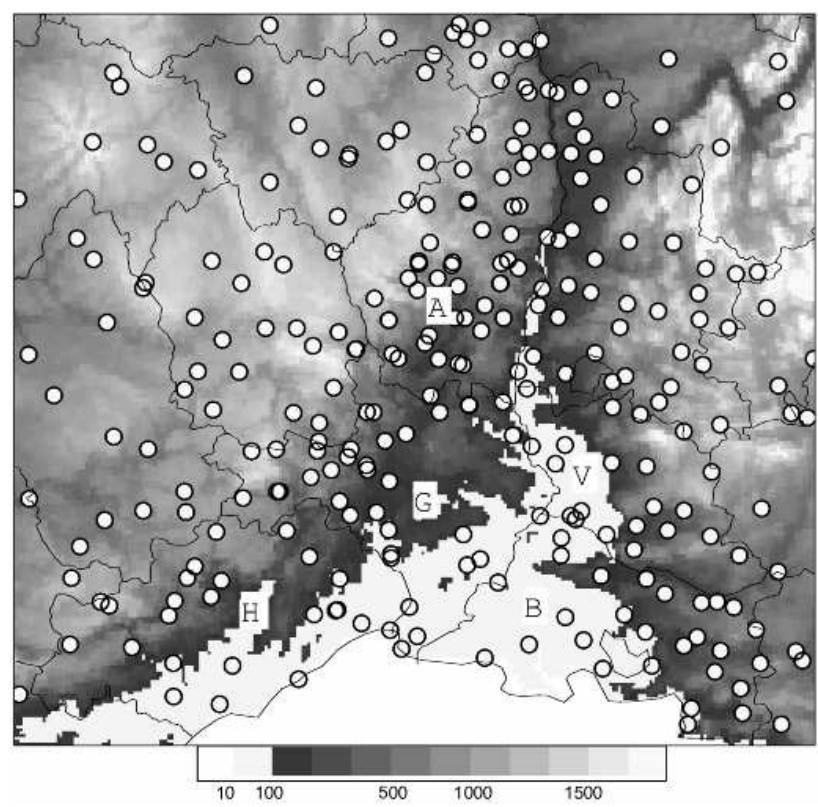

Fig. 13. Location of the rain gauges of the regional high-resolution networks (Météo-France, DDE Ardèche, Gard,...) superimposed to relief of South-Eastern France. Departments are displayed in solid black line: A for the Ardèche Department, G for Gard, V for Vaucluse, $\mathrm{H}$ for Hèrault, $\mathrm{B}$ for Bouches-du-Rhône. See Fig. 1 for the localization of the area.

Tanaro and Bormida rivers. It is important to emphasize the situation of the soil which was already saturated because of the particularly rainy period from the beginning of the month and, therefore, it amplified the response of the basins. In any case, the effects were not relevant also because only rural areas were hit: there were problems in the smallest rivers because of the obstruction effect near bridges; there were serious damages to a pillar of a bridge of a highway next to the border with Liguria; the sliding of the slope also affected some vineyards of the area; no casualties were registered during the entire event.

\section{Analysis of the Gard event}

\subsection{Synoptic conditions}

During 8 and 9 September 2002, a heavy precipitation system affected the Gard region, Southern France (Fig. 13), causing enormous damages and loss of human lives.

The system was generated by an upper-level cold low centred over Ireland, extended meridionally to the Iberian Peninsula, which created a South-Westerly flow over SouthEastern France (Fig. 14) (Delrieu et al., 2005).

At surface and ahead of the trough a front undulated over Western France (Fig. 15).

Convection formed well ahead of the surface cold front, in the warm sector, where low-level South-Easterly flows pre-

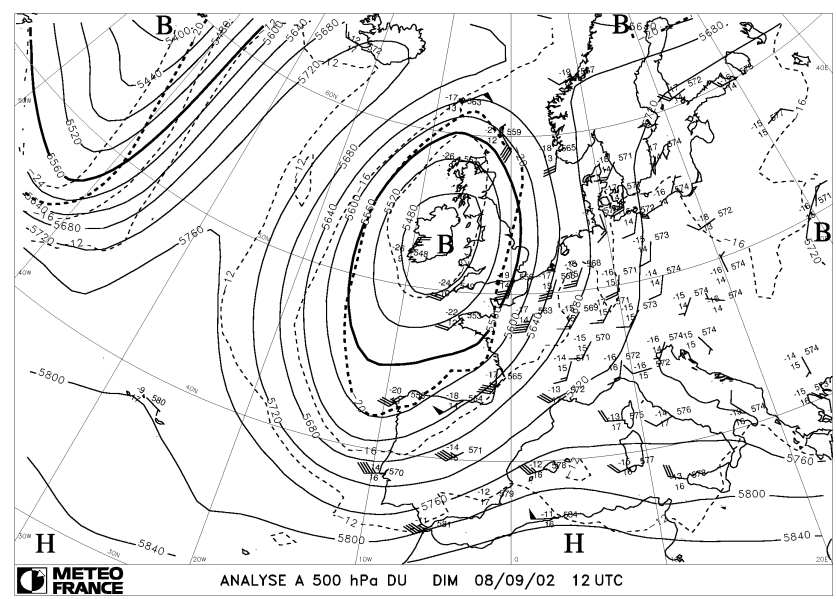

Fig. 14. 8 September 2002 12:00 UTC, analysis at $500 \mathrm{hPa}$ : geopotential (in $\mathrm{m}$ ) and temperature (in ${ }^{\circ} \mathrm{C}$ ) are drawn, respectively, as solid and dashed lines ( $\mathrm{H}$ for high centre and $\mathrm{B}$ for low centre of geopotential).

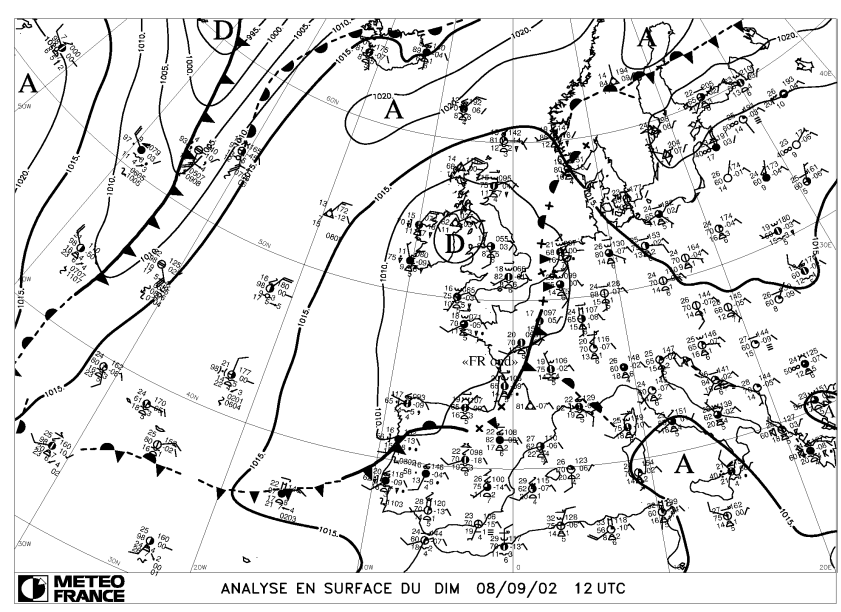

Fig. 15. 8 September 2002 12:00 UTC, surface analysis: slp (in $\mathrm{hPa}$ ) is shown by solid lines (A for high centre and D for low centre of slp).

vailed. Prior to the development of the convection, the atmosphere was conditionally unstable in this region as evidenced by a significant CAPE value on the midnight Nîmes sounding of 8 September (about $850 \mathrm{Jkg}^{-1}$ at 00:00 UTC as shown in Fig. 16).

Precipitable water computed by the radiosoundings shows that the humidity content of the atmosphere was already high $(33 \mathrm{~mm})$ and in particular this value was on the upper $10 \%$ of the distribution of precipitable water for this radiosounding between 1994 and 2003, the average value being $22 \mathrm{~mm}$. After the onset of the convection, the 12:00 UTC radiosounding was almost saturated and the CAPE value still indicated a potential for convective development (Fig. 17). Although these values are punctual, and it is known that CAPE can 


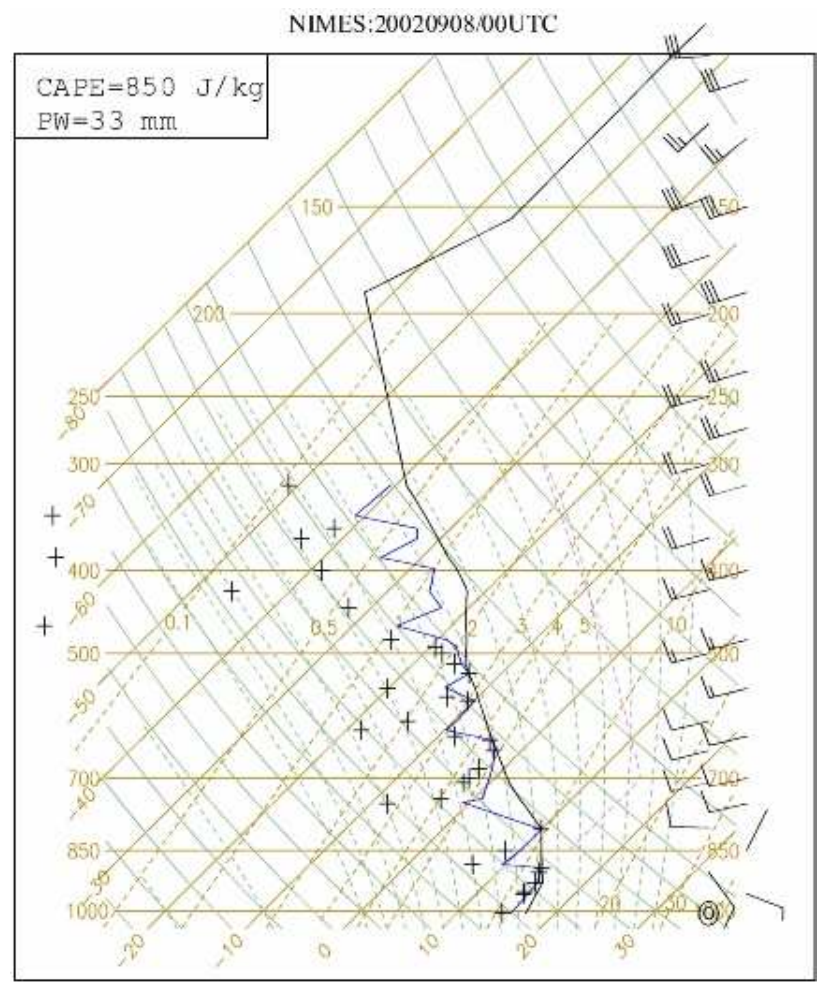

Fig. 16. 8 September 2002 00:00 UTC, Nîmes radiosounding: in the upper-left corner of the panel, CAPE stands for Convective Available Potential Energy $\left(\mathrm{Jkg}^{-1}\right)$ and PW for Precipitable Water (mm). The CAPE computation is based on the most unstable parcel. See Fig. 1 for the location of the station. On the right, the wind direction and intensity is displayed.

have a strong spatial variability, they can be considered as an indication of the local atmosphere instability. During the afternoon and night of 8 to 9 , the surface cold front slowly progressed Eastward and the low-level flow over the Gulf of Lion accelerated. During the same time, the main upper-level deep trough swung into a North-West/South-East orientation leading to an upper South/South-Westerly flow over SouthEastern France (Fig. 18).

As the surface front passed over the Gard region, it contributed to the heavy precipitation, but also swept the convective activity with it (Fig. 19).

Convective cells started to develop over the Western Mediterranean sea around 04:00 UTC, 8 September 2002. They progressed Northward to reach the French coasts where they constituted a quasi-stationary Mesoscale Convective System (MCS) around noon. The quasi-stationary back building MCS assumed the typical V-shape in the infrared imagery due to the interaction of the convection with the Southerly flow (Fig. 20).

New convective cells were continuously generated at the tip of the $\mathrm{V}$, whereas older cells were transported toward the $\mathrm{V}$ branches. It produced high rain intensities and strong

\section{NIMES:20020908/12UTC}

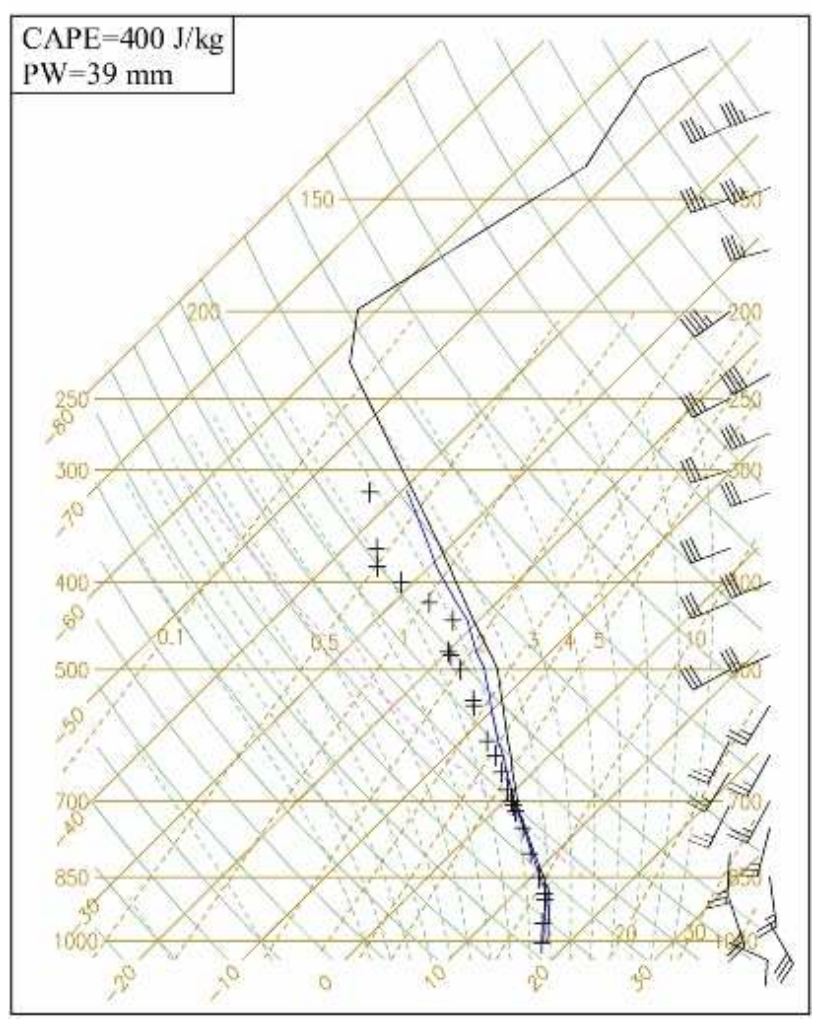

Fig. 17. 8 September 2002 12:00 UTC, Nîmes radiosounding: in the upper-left corner of the panel, CAPE stands for Convective Available Potential Energy $\left(\mathrm{Jkg}^{-1}\right)$ and PW for Precipitable Water (mm). The CAPE computation is based on the most unstable parcel. See Fig. 1 for the location of the station. On the right, the wind direction and intensity is displayed.

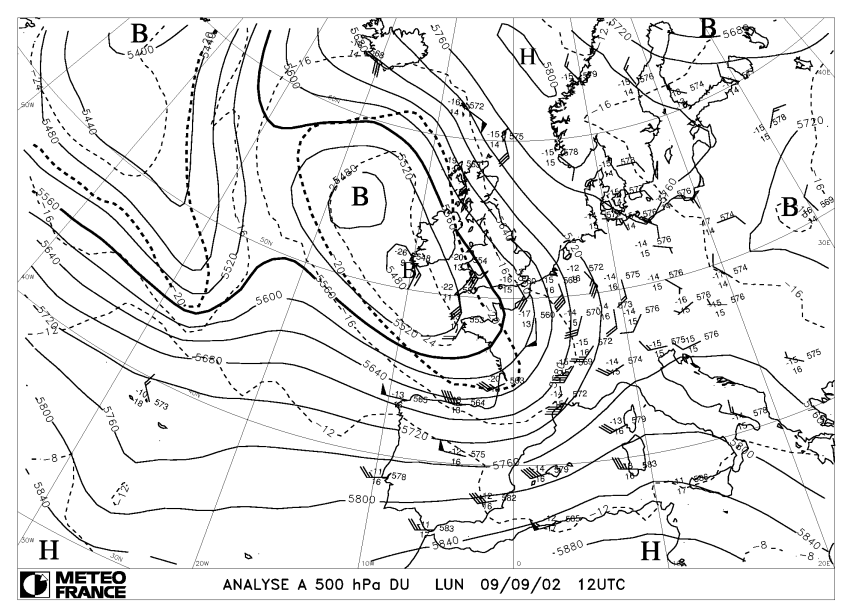

Fig. 18. 9 September 2002 12:00 UTC, analysis at $500 \mathrm{hPa}$ : geopotential (in $\mathrm{m}$ ) and temperature (in ${ }^{\circ} \mathrm{C}$ ) are drawn, respectively, as solid and dashed lines ( $\mathrm{H}$ for high centre and $\mathrm{B}$ for low centre of geopotential). 


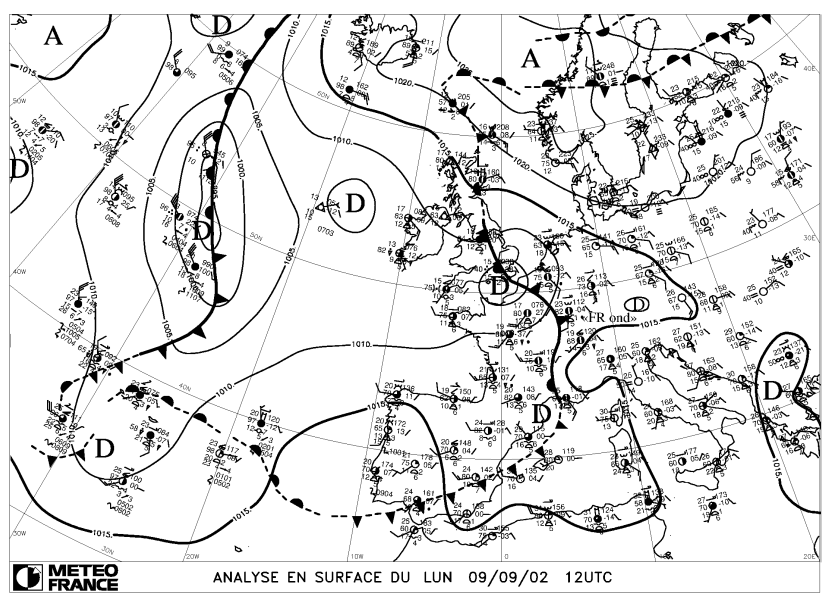

Fig. 19. 9 September 2002 12:00 UTC, surface analysis: slp (in $\mathrm{hPa}$ ) is shown by solid lines (A for high centre and D for low centre of slp).

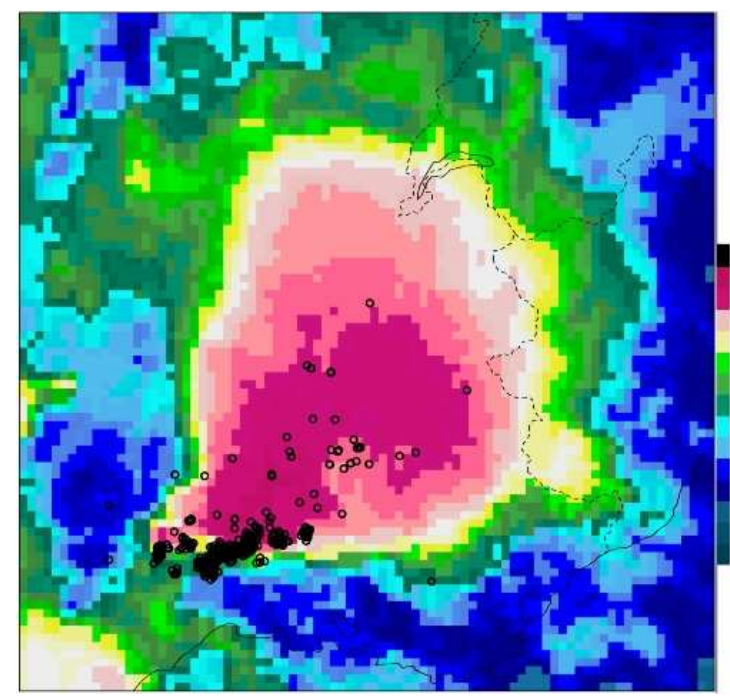

$-81.00$ $-65.00$ $-57.00$ $-49.00$ -41.00
-3.00 $-25.00$ $-17.00$ $-9.00$ 7.00 15.00 23.00 31.00

Fig. 20. 8 September 2002 21:00 UTC, Infrared METEOSAT brightness temperature (in ${ }^{\circ} \mathrm{C}$ ) together with $10 \mathrm{~min}$ Cloud to Ground lightning (circles). See Fig. 1 for the localization of the area.

electrical activity, affecting mainly the Departments of Gard, Herault and Vaucluse. The relief played a fundamental role in the maintenance of the convective activity, since they determined the stationarity of the system (Ducrocq et al., 2003).

\subsection{Analysis of the impacts}

Both the size of the precipitation area and its intensity are exceptional. Precipitation peaks of $680 \mathrm{~mm}$ in $24 \mathrm{~h}$ have been recorded in several places (Fig. 21).

Accumulated rainfall greater than $200 \mathrm{~mm}$ have been recorded on a area of about $5400 \mathrm{~km}^{2}$. Three phases in the
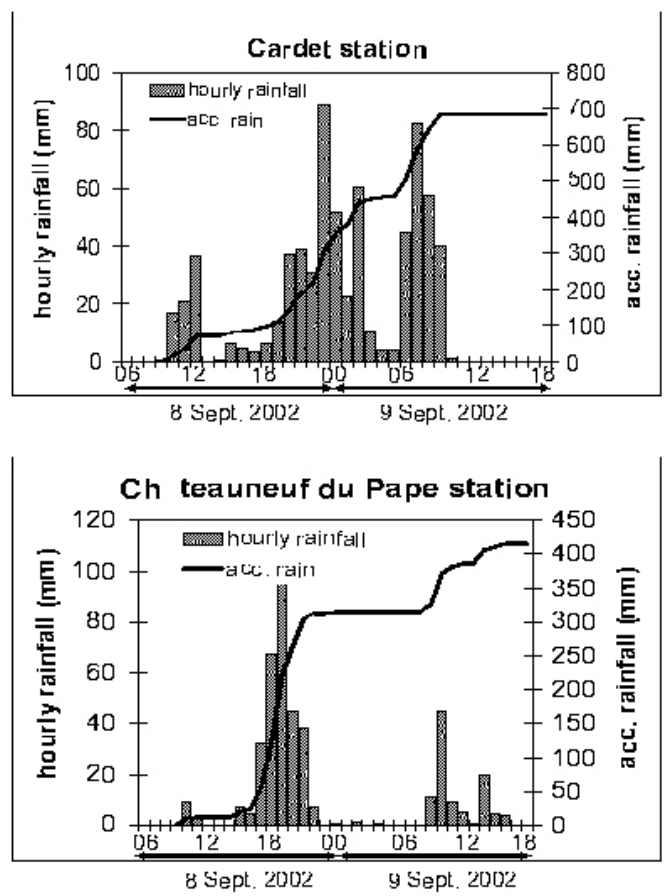

Fig. 21. Hourly rainfall (histogram, scale given at left of the panel) and accumulated rainfall (solid curve, scale given at right of the panel) from 06:00 UTC, 8 September 2002 to 18:00 UTC, 9 September 2002 for two rain gauge stations (see Fig. 22 for location of Cardet (CA) and Châteauneuf du Pape $(\mathrm{CH})$.

precipitation event have been identified (Delrieu et al., 2005) (Fig. 22):

- during the first phase, prior to 22:00 UTC 8 September 2002 , the precipitation induced by the MCS was mainly over the plain region of the Gard and Vaucluse departments;

- then, between 22:00 UTC, 8 September 2002 to 04:00 UTC, 9 September 2002, the MCS shifted toward the upper regions at the limit of the mountain ridge (near Cardet), where it merged with the surface front that has progressed Eastward in the same time;

- after 04:00 UTC, 9 September 2002, the front with the embedded convection moved Eastward and swept again the Gard plain region.

Figure 21 shows the temporal evolution of the hourly rainfall for two rain gauges from the Météo-France rain gauge network; one (Cardet station, see Fig. 22 for the location) is located inside the maximum of daily surface rainfall area in the Gard Department. The second one (Châteauneuf du Pape station), is situated in the plain areas, at the limit of the Gard and Vaucluse department. The Cardet station, is one of the station that has recorded more than $680 \mathrm{~mm}$ in $24 \mathrm{~h}$ in the Gard department. For that station, high rain 


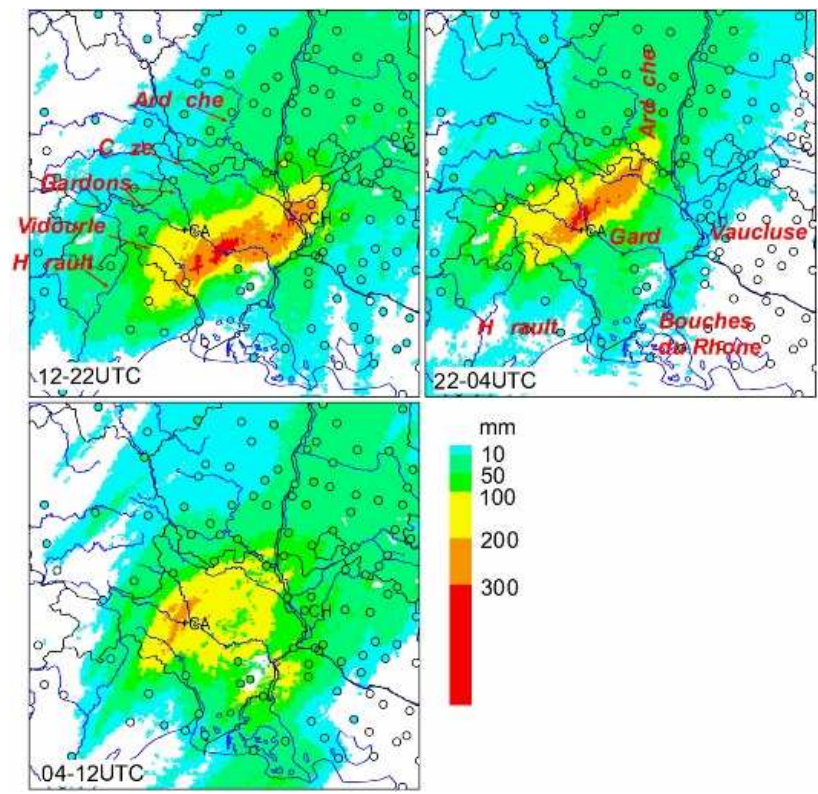

Fig. 22. Accumulated rain gauge rainfall (colored circle) superimposed to radar rainfall from the Météo-France rain gauge and radar networks for the three phases of the event: from 12:00 to 22:00 UTC, 8 September 2002; from 22:00 UTC, 8 September 2002 to 04:00 UTC, 9 September 2002; from 04:00 UTC to 12:00 UTC, 9 September 2002. For the upper left panel, the names of the rivers (blue lines) of the Massif Central region are indicated. For the upper right panel, the names of the Department (black lines) are given. The location of the Cardet (CA) and Châteauneuf du Pape (CH) stations are also indicated. See Fig. 1 for the localization of the area.

rates have been recorded, with $90 \mathrm{~mm}$ in one hour between 22:00 and 23:00 UTC, 8 September. For the Châteauneuf du Pape station, the accumulated rainfall reached more than $400 \mathrm{~mm}$ in $24 \mathrm{~h}$ with a time evolution of the hourly precipitation that clearly identified the three phases of the event: before 22:00 UTC, the quasi-stationary MCS induced large rain rates over the region, then precipitation almost vanished between 22:00 UTC and 07:00 UTC the day after. Afterward, the front with the embedded convection passed over the region and contributed to increase again the accumulated precipitation.

The flood that took place in this event is namely a flashflood. The strong precipitation caused the swelling of some river like the Cèze, Vidourle, Gardons and Gard. The peak specific discharges (the quantity of water obtained from a basin per time's and surface's unit) were around $5-10 \mathrm{~m}^{3} \mathrm{~s}^{-1} \mathrm{~km}^{-2}$ for these rivers, reaching locally values as high as $20 \mathrm{~m}^{3} \mathrm{~s}^{-1} \mathrm{~km}^{-2}$. The cities where the floods had more impact were Anduze, Alès, Nîmes, Aramon, Bessèges and Sommières. The floods destroyed numerous cars, houses, factories and commerce and 24 casualties were recorded. The water and electricity networks had to interrupt their services and the total amount of damages ascended to 1.2 billion euros (Huet et al., 2003).

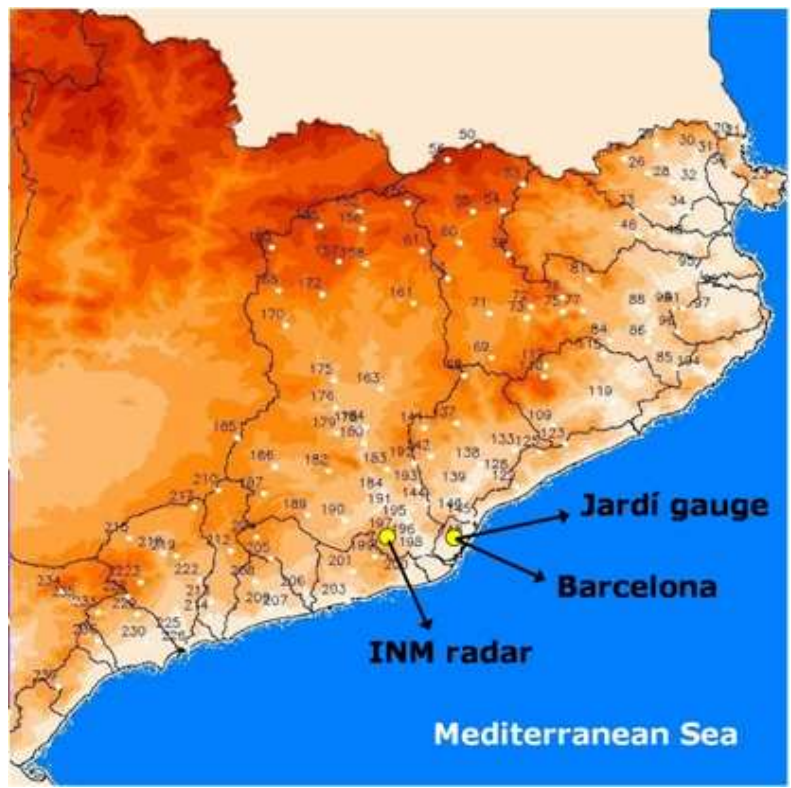

Fig. 23. Location of the rain gauges of the high resolution network of Catalonia. See Fig. 1 for the localization of the area.

\section{Analysis of the Montserrat event}

\subsection{Synoptic conditions}

The synoptic situation on 9 June 2000 shows the entry from the Western part of the Iberian Peninsula of a cold front associated with a low situated to the North of the British Isles, while Catalonia (Fig. 23) was under the influence of an anticyclone that affected Central and Eastern Europe and much of the Western Mediterranean Sea (Fig. 24 and Fig. 25). The upper-level cold trough, the axis of which was situated at 00:00 UTC over Portugal, gave rise to cold Westerly winds over the Western sector of the Iberian Peninsula, and to warm Southerly winds over the Eastern sector.

On 10 June at 00:00 UTC the cold front was situated around the Greenwich meridian, to the West of Catalonia. At that time a sea level pressure minimum formed, centred over the Balearic Islands, reaching $1008 \mathrm{hPa}$ (Figs. 26 and 27). The Westerly flow that dominated most of the Peninsula had been veering, so that by the time it was coming mainly from the North and had advected very cold air that extended right to the upper troposphere and was responsible for the snow that fell that day over the North and centre of Spain (López and Arán, 2005).

But that was not the only factor responsible for the torrential rains recorded in Catalonia. Indeed, the dominant synoptic situation in this region on 10 June between 00:00 UTC and 12:00 UTC, the interval over which practically all the rain fell, showed a conjunction of the following factors (Llasat et al., 2003): 


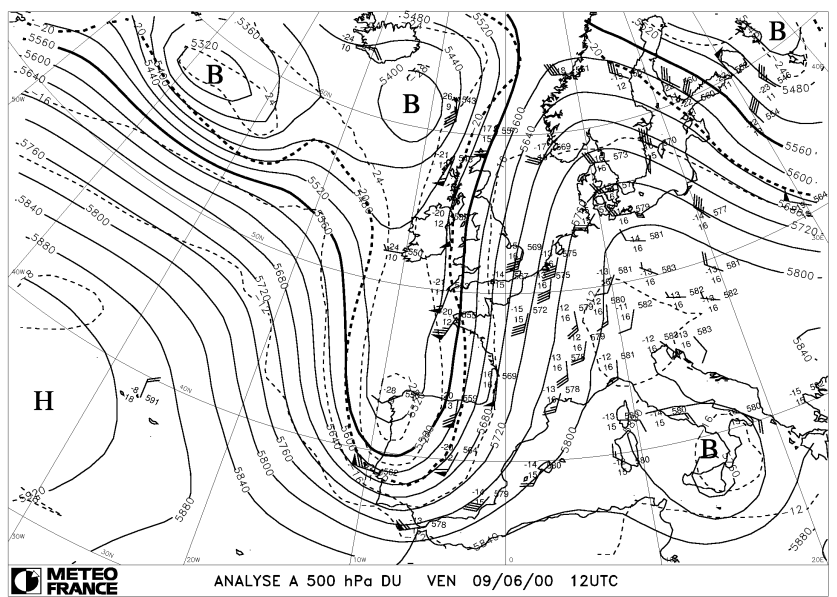

Fig. 24. 9 June 2000 12:00 UTC, analysis at $500 \mathrm{hPa}$ : geopotential (in $\mathrm{m}$ ) and temperature (in ${ }^{\circ} \mathrm{C}$ ) are drawn, respectively, as solid and dashed lines ( $\mathrm{H}$ for high center and $\mathrm{B}$ for low centre of geopotential).

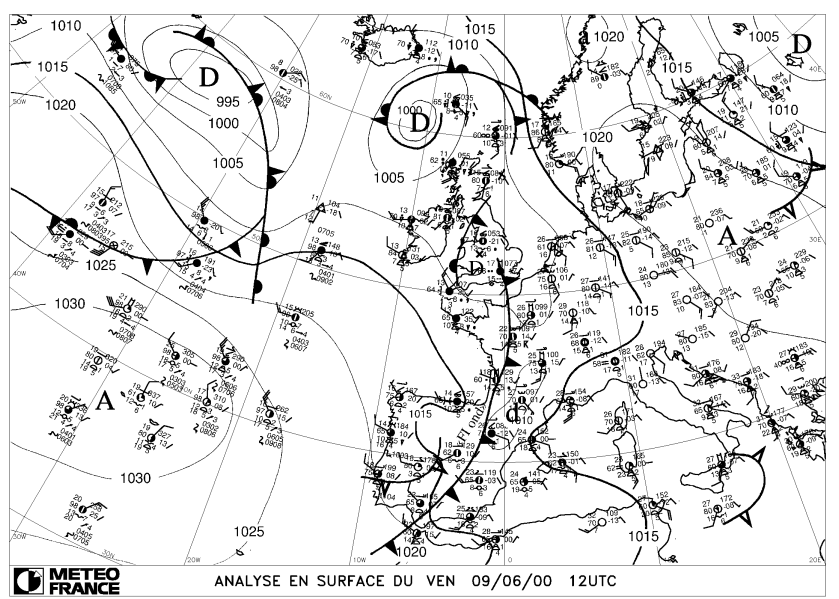

Fig. 25. 9 June 2000 12:00 UTC, surface analysis: slp (in hPa) is shown by solid lines (A for high centre and $\mathrm{D}$ for low centre of slp).

- A mesoscale depression (meso- $\alpha$ ) at surface which extended from the Balearic Islands to Catalonia and led to the convergence of water vapour at low levels, playing a direct part in triggering the potential instability accumulated previously (the location of the convective system on the radar imagery pointed to the existence of a line of convergence that was advancing over Catalonia along a South-West/North-East axis);

- A strong wind from the East/South-East at lower levels (more than $30 \mathrm{kt}$ at $950 \mathrm{hPa}$ ) and from the South/SouthWest at upper levels over the affected area, that favoured the production of multicellular storms. This moist flow from the Western Mediterranean impinged perpendicularly to the mountain ranges;

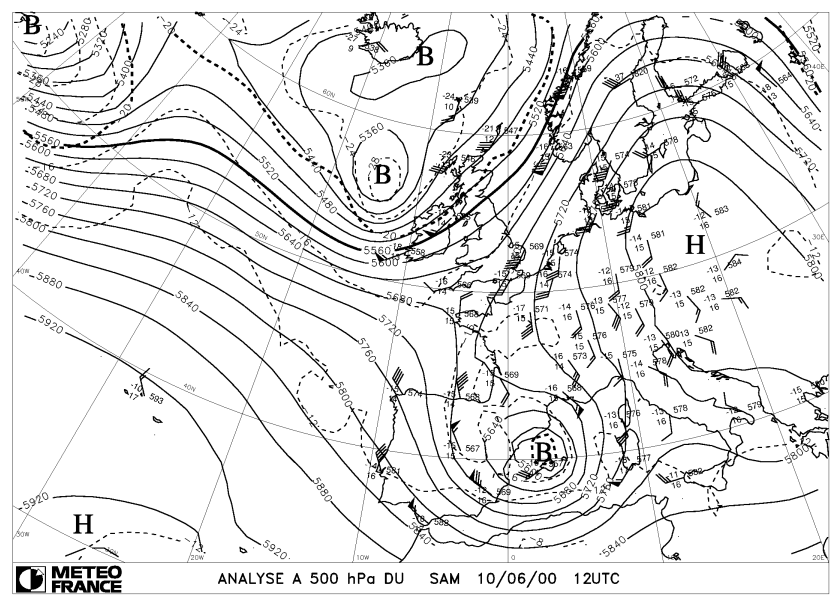

Fig. 26. 10 June 2000 12:00 UTC, analysis at $500 \mathrm{hPa}$ : geopotential (in $\mathrm{m}$ ) and temperature (in ${ }^{\circ} \mathrm{C}$ ) are drawn, respectively, as solid and dashed lines ( $\mathrm{H}$ for high centre and $\mathrm{B}$ for low centre of geopotential).

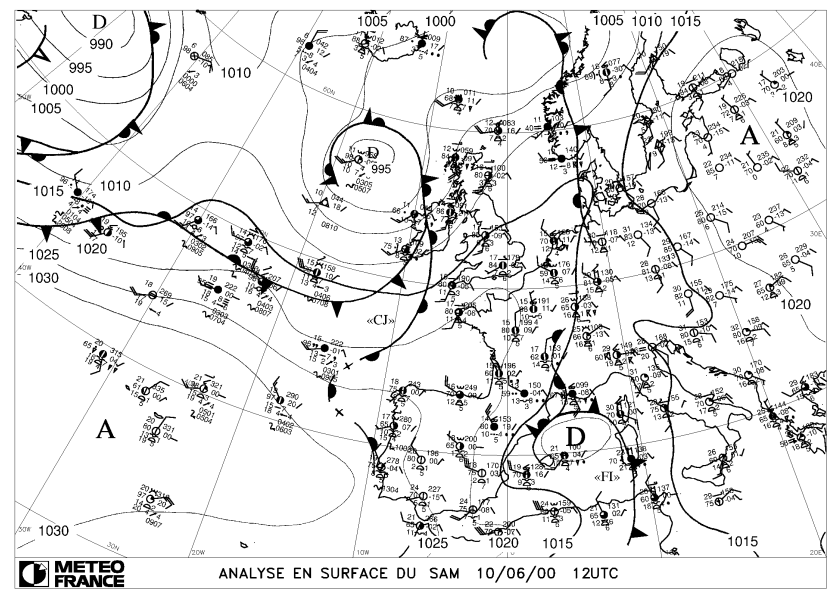

Fig. 27. 10 June 2000 12:00 UTC, surface analysis: slp (in hPa) is shown by solid lines (A for high centre and D for low centre of slp).

- A strong orographic component in focusing and sustaining the convection, which combined with the advance of the depression at low levels.

Analysis of the CAPE shows a significant maximum exceeding $1600 \mathrm{Jkg}^{-1}$ in Palma de Mallorca on 10 June at 00:00 UTC (Fig. 28). At the same time the precipitable water mass had a maximum of $17 \mathrm{~mm}$ between the surface and $850 \mathrm{hPa}$.

This high concentration of water vapour at low levels was a result of the anticyclonic situation that had been prevailing over previous days. The convergence line created by the mesoscale low was enough to trigger the instability. The fact that the rainfall was most intense in the mountainous regions shows the important role of topography in the development of convection, with forced updrafts between 500 and $1500 \mathrm{~m}$. 


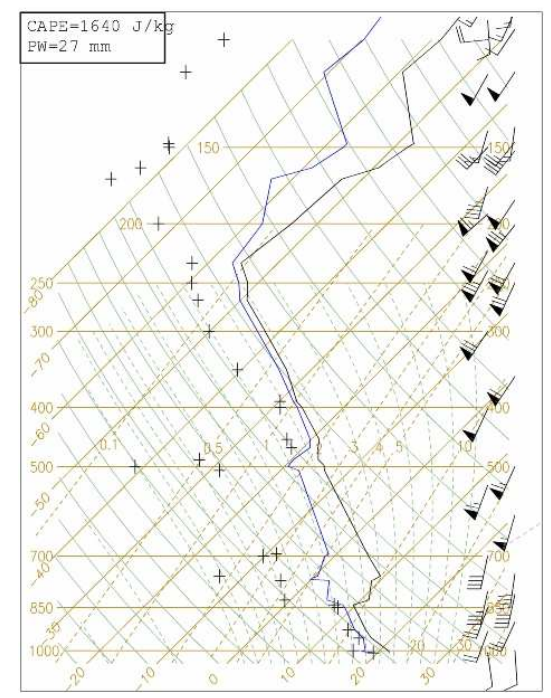

Fig. 28. 10 June 2000 00:00 UTC, Palma de Mallorca radiosounding: in the upper-left corner of the panel, CAPE stands for Convective Available Potential Energy $\left(\mathrm{Jkg}^{-1}\right)$ and PW for Precipitable Water $(\mathrm{mm})$. The CAPE computation is based on the most unstable parcel. See Fig. 1 for the location of the station. On the right, the wind direction and intensity is displayed.

In this case, the mountains were also important in favouring the stationarity of the convective systems.

\subsection{Analysis of the impacts}

The maximum rainfall was recorded over the Llobregat basin, close to the Montserrat Mountain, with $224 \mathrm{~mm}$ in Rajadell and $202 \mathrm{~mm}$ in Sant Salvador de Guardiola (Fig. 29).

More than $80 \%$ of this precipitation was recorded in less than $6 \mathrm{~h}$. As a consequence of this heavy and sudden rainfall, some flash floods were produced in different Llobregat tributaries and wadis that are normally dry. The Llobregat river experienced a swelling of more than $4.5 \mathrm{~m}$ in Castellbel i el Vilar, with a maximum flow of $1100 \mathrm{~m}^{3} \mathrm{~s}^{-1}$ at 09:00 UTC on 10 July. A similar problem arose over the Riera de la Bisbal and Francolí basins, where some wadis that cross the Vendrell village were overflowed producing great damages, due to the heavy rainfalls along all their way, with a maximum of $134 \mathrm{~mm}$ in La Bisbal in less than $3 \mathrm{~h}$. In total, more than $50 \mathrm{~mm}$ were recorded on 10 July in an area of about $16000 \mathrm{~km}^{2}$. Those rainfalls were produced by two MCS's that moved slowly from the South-West to the North-East, remaining stationary over different places for two hours or more (Rigo and Llasat, 2005). Successively the system, composed by different convective cells, remained over the Tarragona basins and over the mountains of the centre of Catalonia (mainly over the Montserrat Mountain area).

The estimated damages were $\approx 65000000$ euros and 5 people died. There was a partial destruction of infrastructures of the enclosure of the Monastery of Montserrat, the

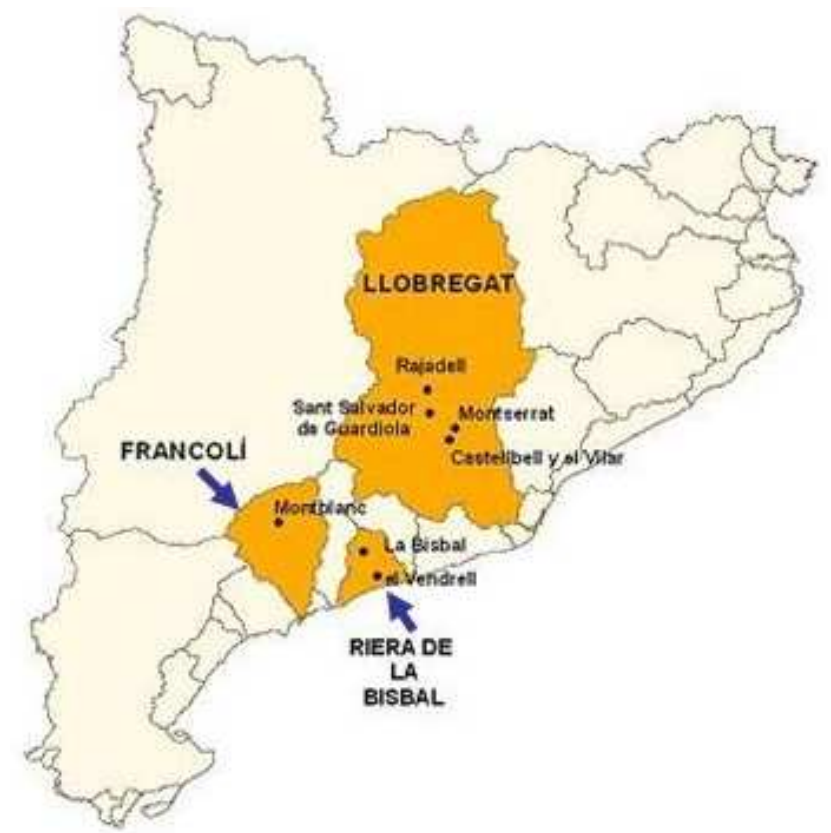

Fig. 29. Location of the most affected places of Catalonia. See Fig. 1 for the localization of the area.

destruction of some routes of access to the mountain, the total destruction of a bridge of one of Catalonia's highways. Moreover, serious damages were produced in very populated coastal and tourist areas with total or partial destructions in commercial zones, cuts in the electrical network, telephone provisions, potable water and partial loss of transport routes.

\section{Conclusions}

We analysed four cases of severe precipitation over three different Western Mediterranean regions with the aim of finding a link among them and a relationship between the large scale forcing and the local orographic effect. In details, we described the events from the meteorological (synoptic) and from the hydrological (local effects) point of view, trying to identify the similarities and the discrepancies.

These events could also be compared with two of the most important floods happened in the past in Piedmont and which were subject of a number of studies (see for instance Buzzi et al., 1998, and Gabella and Mantovani, 2001): the November 1994 and October 2000 floods.

In fact, the disastrous flood that occurred in Southern Piedmont at the beginning of November 1994, associated with heavy rainfall episodes over a relatively small area during 3 to 6 November 1994, was generated by a quasi-stationary cyclonic area over Western Europe (A.R.P.A. Piemonte, 1997). The most intense rainfall (for which values over $200 \mathrm{~mm}$ were reported) occurred in two regions located in the upper reach of the Tanaro and Bormida river basins and over the North-West sector of the Alps. The intense rainfall over these 
two mountain areas was enhanced by the confluence of the surface South-Easterly flow and of the upper-level Southerly current. This confluence was strongest over the two zones in which the maxima of rainfall and vertical wind velocity were observed.

Also between 13 and 16 October 2000, another tremendous flood affected Piedmont with extreme and persistent precipitation, in particular over the North-Western area of the region: values exceeding $600 \mathrm{~mm}$ in four days have been reported over the Alps, causing huge damages and loss of lives (A.R.P.A. Piemonte, 2000). During those days, the Western Europe was interested by a quasi-stationary deep trough over Great Britain associated to a minimum of sea level pressure, which caused a constant strong Southerly flow all over the Alps. In a second time, the trough cut-off over the Alps generating an upper-level low associated to a sea level pressure minimum in the North Tyrrhenian Sea which continued to bring moist flow over Piedmont both at lower and at higher levels of the atmosphere.

In summary, some common ingredients to the cases can be drawn:

- Presence of a deep trough extended from the British Islands to the Iberian Peninsula generating a South to South-Westerly moist flow in the mid to upper troposphere over the regions;

- Slow moving patterns at synoptic scale, which allow the stationarity of the precipitating systems;

- At low-levels, strong wet meridional winds impinging the relief of the regions, favouring triggering of deep convection or enhancement of the precipitation over the upwind flanks of the mountain ranges.

All these ingredients favoured either slow-moving frontal systems or/and quasi-stationary convective systems with large amounts of precipitation accumulated, for the former, in several days and leading to extended floods (Piedmont cases), or for the second type of events, accumulated in less than one day and inducing flash-floods (Gard and Montserrat cases).

The orographic forcing induced by the South to Easterly low-level winds that face the mountains of the Western Mediterranean countries constitutes an omnipresent stationary low-level forcing (Llasat et al., 2000), but it is not the only one; upwind low-level convergence associated with cyclogenesis over the Western Mediterranean Sea (Montserrat case) or blocked cold pool generated by the convection itself (Gard case) can trigger and maintain deep convection over the same area during several hours.

Acknowledgements. The authors wish to acknowledge all the HYDROPTIMET partners for the strong collaboration demonstrated during the project. Moreover we would like to thank the Agencia Catalana de l'Aigua (Generalitat de Catalunya) for the rainfall data of the Spanish case.
Edited by: R. Romero

Reviewed by: V. Homar and another referee

\section{References}

Anquetin, S., Yates, E., Ducrocq, V., Samouillan, S., Chancibault, K., Davolio, S., Accadia, C., Casaioli, M., Mariani, S., Ficca, G., Gozzini, B., Pasi, F., Pasqui, M., Garcia, A., Martorell, M., Romero, R., and Chessa, P.: The 8 and 9 September 2002 flash flood event in France: a model intercomparison, Nat. Hazards Earth Syst. Sci., 5, 741-754, 2005.

A.R.P.A. Piemonte: Eventi alluvionali in Piemonte (2-6 novembre 1994-8 luglio 1996 - 7-10 ottobre 1996). Agenzia Regionale per la Protezione Ambientale del Piemonte, 1997.

A.R.P.A. Piemonte: Rapporto sull'evento alluvionale del 13-16 Ottobre 2000. Agenzia Regionale per la Protezione Ambientale del Piemonte, http://www.arpa.piemonte.it (in Italian), 1-113, 2000.

A.R.P.A. Piemonte: Rapporto sugli eventi meteorologici del Novembre 2002. Agenzia Regionale per la Protezione Ambientale del Piemonte, http://www.arpa.piemonte.it (in Italian), 1-74, 2002.

Arreola, J. L., Romero, R., Homar, V., Ramis, C., and Alonso, S.: Multiscale numerical study of the 10-12 November 2001 strong cyclogenesis event in the Western Mediterranean, Proc. 4th EGS Plinius Conference held at Mallorca, Spain, October 2002

Boni, G., Conti, M., Dietrich, S., Lanza, L., Marzano, F. S., Mugnai, A., Panegrossi, G., and Siccardi, F.: Multisensor observations during the flood event of 4-6 November 1994, over Northern Italy, Remote Sensing Rev., 14(1-3), 91-117, 1996.

Buzzi, A., Tartaglione, N., and Malguzzi, P.: Numerical simulations of the 1994 Piedmont flood: Role of orography and moist processes, Mon. Wea. Rev., 126, 2369-2383, 1998.

Chastan, B., Gilard, O., and Lavabre, J.: Les difficultés d'estimation rapide des débits observés en crue: exemple de la crue de l'Ouvèze du 22 septembre 1992, Rev. de Geographie de Lyon (in French), 68, 2-3, 153-158, 1993.

Comby, J.: Bilan social et économique de la séquence orageuse du 22 septembre 1992 dans le sud du couloir rhodanien, Rev. de Geographie de Lyon (in French), 68, 2-3, 175-192, 1993.

Cressman, G. P.: An operational objective analysis system, Mon. Wea. Rev., 87, 367-374, 1959.

Delitala, A. M. S.: Perception of intense precipitation events by public opinion, Nat. Hazards Earth Syst. Sci., 5, 499-503, 2005.

Delrieu, G., Ducrocq, V., Gaume, E., Nicol, J., Payrastre, O., Yates, E., Kirstetter, P. E., Andrieu, H., Ayral, P. A., Bouvier, C., Creutin, J. D., Livet, M., Anquetin, S., Lang, M., Neppel, L., Obled, C., Parent Du Chatelet, J., Saulnier, G. M., Walpersdoff, A., and Wobrock, W.: The catastrophic flash-flood event of 8-9 September 2002 in the Gard region, France: Mediterranean Hydrometeorological Observatory, J. Hydrometeorol., 6, 34-51, 2005.

Doswell III, Ch. A., Brooks, H. E., and Maddox, R. A.: Flash flood forecasting: an ingredients based methodology, Weather Forecasting, 11, 560-581, 1996.

Ducrocq, V., Chancibault, K., Habets, F., and Anquetin, S.: Mesoscale modelling of a flooding storm. Application to the extreme flood of Gard, Mediterranean Storms, Proc. of the 5rd EGS Plinius Conference, Ajaccio, Corsica, France, 1-3 October 2003. 
Elementi, M., Marsigli, C., and Paccagnella, T.: High resolution forecast of heavy precipitation with Lokal Modell: analysis of two case studies in the Alpine area, Nat. Hazards Earth Syst. Sci., 5, 593-602, 2005.

Gabella, M. and Mantovani, R.: The floods of 13-16 October 2000 in Piedmont (Italy): Quantitative precipitation estimates using radar and a network of gauges, Weather, 56, 337-343, 2001.

Huet, P., Martin, X., Prime, J. L., Foin, P., Laurain, C., and Cannard, P.: Retour d'expérience des crues de septembre 2002 dans les départements du Gard, de l'Hérault, du Vaucluse, des Bouchesdu-Rhone, de l'Ardèche et de la Drôme. Tech. Rep. (in French), Ministère de l'écologie et du développement durable, 2003.

Lacava, T., Greco, M., Di Leo, E. V., Martino, G., Pergola, N., Sannazzaro, F., and Tramutoli, V.: Monitoring soil wetness variations by means of satellite passive microwave observations: the HYDROPTIMET study cases, Nat. Hazards Earth Syst. Sci., 5, 583-592, 2005.

Llasat, M. C., Ramis, C., and Lanza, L.: Storm Tracking and Monitoring Using Objective Synoptic Diagnosis and Cluster Identification from Infrared Meteosat Imagery: A Case Study, Meteorol. Atmos. Phys., 71, 139-155, 1999.

Llasat, M. C., Rigo, T., and Montes, J. M.: Orographic role in the temporal and spatial distribution of precipitation. The case of the internal basins of Catalonia (Spain), Proceedings of the EGS Plinius Conference held at Maratea, Italy, October 1999, 41-55, 2000.

Llasat, M. C., Rigo, T., and Barriendos, M.: The 'Montserrat-2000' flash-flood event: a comparison with the floods in the NorthEastern Iberian Peninsula since the 14th century, Int. J. Climatol., 23, 453-469, 2003.

López, J. M. and Arán., M.: Estudio de una ciclogénesis rápida mediterránea: Cataluña, 9-10 de junio de 2000 (in Spanish), Serie Monografías. Instituto Nacional de Meteorología, 108 pp, 2005.

Mariani, M., Casaioli, C., Accadia, M., Llasat, C., Pasi, F., Davolio, S., Elementi, M., Ficca, G., and Romero, R.: A limited area model intercomparison on the "Montserrat-2000" flashflood event using statistical and deterministic methods, Nat. Hazards Earth Syst. Sci., 5, 565-581, 2005.

Mission Inter-Service de l'Eau: La crue du 26 Septembre 1992 dans les Pyrénées Orientales. La plus forte depuis l'aiguat d'Octobre 1940. Direction Départamentale de l'Agriculture et de la Fôret (in French). Direction Départamentale de l'Equipement, France, 48 pp, 1993.
Plaut, G., Schuepbach, E., and Doctor, M.: Heavy precipitation events over a few Alpine sub-regions and the links with largescale circulation, 1971-1995, Climate Res., 17, 285-302, 2001.

Rabuffetti, D. and Milelli, M.: The hydro-meteorological chain in Piemonte region, North Western Italy - analysis of the HYDROPTIMET test cases, Nat. Hazards Earth Syst. Sci., 5, 845852, 2005.

Ramis, C., Llasat, M. C., Genovés, A., and Jans, A.: The October87 floods in Catalonia. Synoptic and mesoscale mechanisms, Meteorol. Appl., 1, 337-350, 1994.

Rigo, T. and Llasat, M. C.: Radar analysis of the life cycle of Mesoscale Convective Systems during the 10 June 2000 event, Nat. Hazards Earth Syst. Sci., 5, 959-970, 2005.

Riosalido, R., Ferraz, J., Alvarez, E., Cansado, A., Martín, F., Elízaga, F., Camacho, J. L., and Martín, A.: A flash flood event in the Spanish Pyrenees: the Biescas case, INM/WMO International Symposium on cyclones and hazardous weather in the Mediterranean, Palma de Mallorca, 151-158, April, 1997.

Romero, R., Martín, A., Homar, V., Alonso, S., and Ramis, C.: Predictability of prototype flash flood events in the Western Mediterranean under uncertainties of the precursor upper-level disturbance: the HYDROPTIMET case studies, Nat. Hazards Earth Syst. Sci., 5, 505-525, 2005.

Rotunno, R. and Ferretti, R.: Mechanisms of Intense Alpine Rainfall, J. Atmos. Sci., 58, 1732-1748, 2001.

Sénési, S., Bougeault, P., Chèze, J.-L., Cosentino, P., and Thepenier, R.-M.: The Vaison-la-Romaine Flash Flood: Meso-Scale Analysis and Predictability Issues, Wea. Forecasting, 11, 417-442, 1996.

Taramasso, A. C., Gabellani, S., and Parodi, A.: An operational flash flood forecasting chain applied to the test cases of the EU project HYDROPTIMET, Nat. Hazards Earth Syst. Sci., 5, 703710, 2005.

Zampieri, M., Malguzzi, P., and Buzzi, A.: Sensitivity of quantitative precipitation forecasts to boundary layer parameterization: a flash flood case study in the Western Mediterranean, Nat. Hazards Earth Syst. Sci., 5, 603-612, 2005. 